\title{
Impossible Representations \\ Visions of China and the West in Flower in a Sea of Retribution
}

\author{
Works of art ... indifferent to their mode of presentation \\ would negate their own concept. \\ Theodor Adorno, "Extorted Reconciliation: On Georg \\ Lukács' Realism in Our Time"
}

At the heart of the search for Chinese modernity in Chinese thinking and in some of China's most important intellectuals stands a huge paradox.

Wang Hui, "Contemporary Chinese Thought and the

Question of Modernity"

\begin{abstract}
In the autumn of 1895, after China's catastrophic defeat by Japan, the Zongli yamen (Office of Foreign Affairs) responded by instituting special classes within the ministry to teach foreign languages. ${ }^{1}$ Zeng $\mathrm{Pu}$, a well-connected young juren degree holder, went north from his home in Jiangsu to attend these classes. Zeng was one of the few who enrolled in the French section, a choice that was to have a significant impact on the rest of his life. For all the good intentions evident in instituting the new course of instruction, the classes quickly failed: the teachers, apparently officials returned from overseas duty, had no interest or skill in instructing, and the students felt they had better things to do than attend class. ${ }^{2}$ Among the students, it seems, only Zeng Pu took the course seriously and devoted himself sedulously to learning French, sensing that knowledge of Western culture would be indispensable to successful reform within China. Even after the dissolution of the formal course, Zeng continued to study French on his own, embarking upon a course of self-study of works of literature and history written in that language.
\end{abstract}


After a short period in which he tried to educate himself in French literature, Zeng eventually encountered Chen Jitong (1851-1907), a graduate of the Fuzhou Shipyard School of Navigation who had studied in the French-language track there. ${ }^{3}$ Chen provided Zeng the bibliographic guidance he had theretofore lacked, and from that point on, the younger man procured books in French. As he put it, "[I] developed a literary mania (wenxue kuang), sleeping neither night nor day, until I contracted a serious illness. Once I became sick, I stayed sick for five years." ${ }^{4}$ As is clear from the examples provided by Liang Qichao and Zhang Taiyan that were discussed in chapter 3 , this almost religious sense of dedication to newly discovered Western cultural work is by no means uncommon in retrospective accounts by Chinese intellectuals of their activities in the 1890 s, especially for the period after 1895, when defeat by Japan brought the realization that a more active engagement with Western political ideas and technological organization would be indispensable to national survival. Meanwhile, probably in early 1903, Jin Songcen had begun work on a political novel intended to track China's relations with Russia through a depiction of the Chinese envoy to that country, Hong Jun, including as a secondary character the concubine who accompanied him on his foreign travels, the famous courtesan Sai Jinhua (1874-1936). The first two chapters were published at the end of $1903 .{ }^{5}$ In 1904, after having completed six chapters, Jin recognized his lack of sympathy with the novel form and turned the work over to $\mathrm{Zeng} \mathrm{Pu}$, then still recovering from his illness. Zeng had also become one of the founders of the Xiaoshuo lin she, a publishing house that was primarily devoted to translating Western fiction and in 1907-1908 published the fiction journal Xiaoshuo lin. ${ }^{6}$ The two men agreed upon the general subject matter to be covered in the book's sixty projected chapters. ${ }^{7}$

Building upon Song's draft of the first six chapters, Zeng soon completed twenty chapters of the novel entitled Niehai hua (Flower in a sea of retribution). These chapters were published together in book form in 1905 , and the work was immediately hugely popular with the urban reading audience. According to Zeng's own and thus perhaps overoptimistic estimate, the book went through as many as fifteen printings in the years following its first publication and sold close to fifty thousand copies, a vast number for the new publishing market that had arisen in Shanghai at the end of the Qing. ${ }^{8}$ It was virtually unique for its time in not having been first serialized in a magazine, and the relatively sympathetic portrait it presents of Russian anarchists also sets it apart from the rather more conservative novels by writers like Wu Jianren, Li Baojia, and Liu E. As Zeng noted in his 1928 remarks on the text, "[T] he core meaning of this book consists of my view of how during the thirty years [covered in the text, 1868-1898], our China went through a huge transformation from 
new to old, consisting of one part cultural development (tuiyi) and one part political change. Phenomena both alarming and pleasing occurred in this period one upon the other." 9

One of the most striking things about the novel is the prominence given to representations of the foreign, in both the unfolding of the plot and the development of the principal characters. ${ }^{10}$ This figuration of a world that is at once beyond China but has also become, by the time the novel was written, profoundly imbricated with Chinese society is highly complicated. Part of this complexity arises out of a sharp awareness that indigenous knowledge would be lamentably insufficient in the new international age. As was the case with the novels of $\mathrm{Wu}$ Jianren discussed in chapters 5 and 6, there seems to be in Flower in a Sea a profound ambivalence about what the coming of the West means for China. Within the discourse of the novel, Western ideas, no matter how noble and practical they have proved to be in their native terrain, never seem to work once they are imported into China and grafted on to preexisting Chinese ways. When these Western practices come to China, for all the inevitability of their presence, they somehow come to embody a crudity and an amorality that cast doubt on the desirability and even the stability of Chinese participation in the Western-dominated new world order that was emerging in the late nineteenth century. In other words, something about the Chinese narrative context renders the universality of Western ideas problematic.

On the surface this anxiety about the positioning of Western ideas presents a paradox. For all the pressures that the Western powers exerted on the Qing at the turn of the century, China remained in control of its own organs of government and education. That so many powerful nations had interests in China made it exceedingly difficult for them ever to agree on any method of subjecting the huge country to colonial division. Moreover, in the radically transformed post-1895 political situation, what had been the minority position of the Yangwu movement could now easily envision itself as the new and suddenly influential majority in government. And it would be in charge of a bureaucracy that, while admittedly a shadow of its former self, was still staffed by more competent men than most governments the world had ever known. ${ }^{11}$ The uphill struggle to appropriate Western technology and administration piecemeal that had been going since the 1860 s could now metamorphose into policies of sweeping institutional change, something that not even the setback of the failed Hundred Days Reform of 1898 or the Boxer Rebellion of 1900 could really upset. Yet, for all the clear sense of utopian possibility that arose after $1895,{ }^{12}$ there remained an undercurrent profoundly pessimistic about the chances for successful adoption of the new, even among those who professed the most devotion to the need for change. In fact, the 
characteristic rhetoric of the later writings of $\mathrm{Yan} \mathrm{Fu,} \mathrm{who} \mathrm{had} \mathrm{set} \mathrm{in} \mathrm{mo-}$ tion the road map for radical reform in 1895, seems to sound notes of pessimism alien to the discourse on the possibilities of adapting to the new as it had been conducted during the preceding thirty years. ${ }^{13}$ Why was this?

In the recent large and influential corpus of writings on the impact of European colonialism both on the metropole and on the rest of the world, China in particular and East Asia in general have seldom been discussed. ${ }^{14}$ The obvious reason for China's absence in this discourse is that China was never colonized; that is, foreign state powers never gained more than a token foothold within China's borders. The theories of subalternity and of the "colonial subject" that were developed primarily to describe characteristics of British India thus never seem to quite fit China: at the very least, outside of portions of a number of important cities, Chinese people were never subject to the rule of European colonizers. Neither the legal nor the educational structure ever had foreigners in ultimate command, and Chinese always remained the dominant language, both officially and unofficially. Those who were in a position to take upon command of the modernization of China were, therefore, Chinese, rather than colonial administrators. In principle, then, the resentments and resistances we can easily find in scenarios of colonial modernity should be absent, or at least greatly attenuated, in China. Yet this dark cloud remains. Perhaps the best approach to the question is to look at the agenda of modernization rather than at either the personnel in charge or any particular structure of power. In reviewing the demands of the agenda, the differences between the overt colony and China diminish sharply: an educational curriculum built around extended literacy and technical training, industrial structure, and rationalized administration are alike demanded, whether the agent of the demands is the colonial overseer or the national elite desperately trying to develop sufficient national strength to keep colonial power safely at bay.

In fact, one might even argue that holding on to indigenous agency actually made the problem of accommodation more acute. In a place like India, for instance, where the material demands imposed by external force for modernity were so evident and so equally unlikely to flag, it was always possible to hold on to a notion of national essence beyond the realm of practical statecraft and thus equally beyond the reach of the British Raj. ${ }^{15}$ In China, on the other hand, the need for the agency of modernization to emerge exclusively from domestic institutions and people rendered issues of autonomy and their relationship to social function much more problematic. Perhaps an anecdote recounted by $\mathrm{Yan} \mathrm{Fu}$ can help illustrate the problem. Writing in 1895 about how the Chinese military had tried to implement a policy of adopting Western techniques, he reports that the effort has been in vain and provides a specific example: 
Some time ago, during the war with the French [in 1884], the Beiyang army contracted with several dozen German officers. By the time the agreement was settled, there was no further use for them [because the war had ended], so they were sent as training officers to various units. They saw the incompetence of our troops and sought to effect some reforms. Each unit commander where they were stationed, however, regarded them as inimical to his own interests and thereupon raised such a clamor as to have the advisers removed. ${ }^{16}$

In India, by contrast, the Indian army was accepted on all counts as a British organization, and its being run in British fashion generally ceased to be an issue (at least after 1857). Nationalists could, of course, conscientiously object to the institution as a whole, but that the army itself was run on British military lines was beyond contest. The choice, then, was between a thoroughly British establishment or some indigenous alternative completely uninflected by foreign ways. In other words, the question became whether one approved or disapproved of a modern army, not on the extent of the role assigned to foreign advisers. And given British domination of government and the economy, it was easy for Indian nationalists like Gandhi to posit a radical heterogeneity between the modern, British-organized segments of society and the traditional, indigenous sector. Once this distinction was accepted, a notion of building upon an Indian essence provided a clear (if institutionally fuzzy) path for nationalism to establish itself. In China, however, the situation could never be this clear-cut: the battle lines were drawn precisely on issues of political and economic sovereignty within the indigenous structure of the government, and it was never even theoretically possible to distinguish neatly between advisers who were counseling efforts toward a universal modernity and foreign agents intent upon stripping Chinese organizations of their closely guarded autonomy.

Given this built-in inclination, or even nationalist imperative, to resist reorganization on Western lines, reformers like Yan Fu came increasingly to take intransigent stands of their own, if only to resist the assertions eventually arising from the conservatives that to institute reform was tantamount to selling the nation off bit by bit. The various schemes of compromise that suggested a binary division between Chinese spirit and Western force - from "Zhongxue wei ti, xixue wei yong"(Chinese learning as the essence, Western learning as the application), discussed in chapter 2; to "guocui" (national essence) in the early years of this century;17 and on to Liang Qichao's post-World War I attempt to valorize Chinese spirituality over Western materiality and Rabindranath Tagore's similar efforts during his early 1920 s visit to China ${ }^{18}$ - were all impatiently hooted down by reformers who had come to believe that change required the extra lever- 
age of a radical rejection of any handhold the past had on the present. If, as Partha Chatterjee suggests, ". . . it is not just military might or industrial strength, but thought itself, which can dominate and subjugate," 19 the amount at stake alone seemed to guarantee that the struggle over the redefinition of a newly destabilized self and its attendant social responsibilities would be far more fraught with trauma than a struggle in which both goal and agent could be located, if never comfortably so, at least definitely outside. It was precisely in regard to ambiguous circumstances like these that the Chinese Left came up with the formulation of "semicolonial" to refer to a situation in which nominal self-rule masked an underlying imperative to model oneself on the very imperialist regimes that one needed to resist in the first place.

The sharp ambivalence that Flower in a Sea manifests toward the representation of the foreign reflects the contradictory attitudes of late Qing thinkers toward the dramatically transformed circumstances that emerged in China after 1895. These divergent perspectives on the foreign are distinctly encapsulated in the paradox that Western language and learning presented to Chinese thinkers trying to work out the means of accommodation between China and the West in these years. Writers of the period seem to have been constantly struck by contrast between the apparent ease of becoming literate in the alphabetical languages of the West and the equally apparent difficulty for Chinese to master the intricacies of a body of knowledge that was so widely disseminated at all levels of society in the West. This contrast in turn refracts back on the internal structure of Chinese society and its relationship to epistemology: if the linguistic medium of Western learning is so simple, will more people in Chinese society be capable of mastering it? But if, from the contrary perspective, the essence of Western learning is so difficult to comprehend, who exactly will be able to gain intellectual control over this vital new body of knowledge? This problem in turn raises new questions. If there is to be a new regime of learning in China, who is going to be in charge of it? Will it be the old intellectual elite or some new group? Or-and I think this is the most worrisome question we see posed as a continuing subtext in Flower in a Sea-could it be possible that no one is qualified to do the job adequately? The need to master Western learning will not recede, but the possibility of actually doing so retreats to the utopian realm in the strictest sense of the word.

Nowhere is this contradiction more sharply rendered than in the depiction of the relationship between Fu Caiyun (the courtesan-turnedambassador's-wife so transparently modeled on the famous Sai Jinhua) and Jin Wenqing (the fictional counterpart of Hong Wenqing, the Chinese ambassador to several countries in northern Europe), whom she accompanies to northern Europe in 1887. Caiyun is portrayed as someone who, although illiterate in Chinese, quickly masters foreign languages 
(in both spoken and written forms) ${ }^{20}$ and is possessed of sufficient meretricious craftiness to deal with all the odd situations she and her husband, Wenqing, encounter in their travels outside China. For his part, Jin proves utterly incompetent to comprehend the new people and ideas he meets. For all his command of Chinese learning - he was, after all, optimus (zhuangyuan) in the Palace Examination of 1868- he is easily taken advantage of and often ends up a helpless fool once he leaves his homeland. Ironically, the person who most often takes that advantage is his young wife, Caiyun, who uses her easily gained knowledge of Western languages and customs to further her own interests, which are represented more often than not as being in opposition to those of her new husband. The couple thus represents in microcosm the paradox that scholars had been writing about for years before the novel was even begun. Caiyun, with no cultivation in domestic arts and letters, proves extraordinarily adept at mastering the external features of the West, while Jin, for all his learning and evident intellectual ability in the traditional sense, proves incapable of understanding even the most superficial aspects of Western knowledge, much less the fundamental ideas that would allow a deeper understanding of the mysteries of Western success in the world.

The vision of the West and its learning presented in the novel is thus a disheartening one for its early twentieth-century audience: only superficial tricks, which do nothing more (and nothing less) than empower the self-interested, can be mastered. The noble tradition of Chinese learning, on the other hand, not only seems to make it impossible to insinuate oneself into this new and more ignoble world but also offers no clues whatsoever as to how the deeper knowledge of Western technology and statecraft might be acquired. The body of knowledge now classified as indigenous is represented as being practically obsolete. The only replacement on the horizon, however, is a set of serviceable tools for getting on in the world that are as morally questionable as they are easy to acquire for those who are willing to forget their scruples or, more germane to this text, who never attained the level of personal cultivation that would have engendered scruples to begin with. Neither Caiyun nor Wenqing proves up to the task of striking a happy medium that would accommodate the full spectrum of Western learning on the one hand and the adaptation of Chinese ideas to the new era on the other. The true key to the West's knowledge - and, beyond that, to its power - is marked as lying outside both cognitive ranges. It thus stands as a frustrating reminder of Chinese inadequacy in the face of unprecedented challenge.

That the demarcations of the different types of learning and moral capacity are made strictly along gender lines faithfully reflects the usages of the times. For one thing, it was Western missionaries who initiated large-scale education for women, even though there was always the suspicion that it was of inferior quality to that provided for men.21 Thus, since 
female education in the traditional Chinese curriculum, however extensive it may have been, achieved virtually no recognition in that discourse, the relative prominence of women who were educated in the missionarysponsored foreign learning would stand out all that much more. ${ }^{22}$ For another, to the extent that female education figured in educational discourse at all, it tended to be represented at the simple end of the continuum. For instance, the late Qing concern to extend the cultural franchise put great stress on the role of fiction in this process, basing itself on the old cliché that xiaoshuo was the province of the semiliterate-that is, women and children, categories that often were fused together by their constant simultaneous evocation. Finally, even if we read no further than the Pan Jinlian-Wu Song episode of Shuihu zhuan (the pivotal story around which the representations of depravity contained in the late Ming novel Jin Ping Mei are built), it is clear that on occasion women served the figural purpose in Chinese fiction of representing the antithesis to the normative order of the world of males. ${ }^{23}$

These three factors combine to create a sense that representing Caiyun as a readable totality is impossible, that there can be no resolution of her character any clearer than an intensely strange otherness. At first, in her customary environment, she is treated matter-of-factly, with all the disdain her low status implied. Once freed from that context, however, she adapts to the transformed situation like a genie out of the bottle: she can cope with new situations so well that she becomes a person of unpredictable consequence, such that the petty injuries meted out to her as a matter of routine in the past come back to fatally haunt Jin Wenqing.

Late Qing reformers often noted the substantial difference between Chinese and Western scripts that was one part of the paradox presented by Western learning. Writing sometime before 1894, for instance, Zheng Guanying sums up what he takes to be the important differences in relative difficulty:

Chinese writing and speech are completely different from one another, but the shallowest of Western writing is simply speech. For this reason, not only can Western children read easy books after a few years of study, but they can compose letters, essays, and the like. In China, if a child is not of prodigious intelligence, I have never heard of anyone [any child] being able to write letters and essays after only a few years of study. We can thus know that the difference between Chinese and Westerners is not one between intelligence and stupidity but in reality is a matter of the difference in the difficulty of their written languages. ${ }^{24}$

For all the apparent ease of reading Western languages, however, translating them adequately into Chinese is quite another matter: 
For those with the ambition for Western learning, they can buy the translations produced [by the Tongwen guan and the Shanghai Translation Bureau (Shanghai fanyi guan)] and read them. They can thus follow their methods, experiment with them, and investigate them; it seems as if there is no difference from reading the actual Western books. There is, in fact, a serious discrepancy. Translating Western books into Chinese is something for which there is no alternative, but is just somewhat better than having no access to these texts at all. But the translations are far from perfect, for they give but a fragmentary picture. Moreover, the names and things in Western books invariably are things that China does not have, and the diction and tone of these works are completely different from Chinese forms of writing. For these reasons, there is always the concern that translation will result in words that fail to convey the meaning (ci bu da yi) or become a plausible corruption of a text. Beyond that, the number of Western books that detail each realm of knowledge is beyond count, and translations available now are but a tiny fraction of the whole. So how can we possibly grasp the essentials [through translations]? 25

In spite of the ease of the Western languages in themselves, Zheng perceives a larger cultural gap. He blames much of it on a failure of educated Chinese to devote themselves to Western learning with the perseverance that is required, despite all their desire to know more about the West:

Those with an ambition for Western learning are either content with a mere smattering of knowledge (qian chang zhe zhi), or float over it hastily without specializing, or only grasp the superficialities to no substantial advantage. The upshot is that no one has mastered any technique that allows us to soar (xiehang) with the Westerners. Why is this? Because our languages differ. So although their language is easy and obvious in the extreme, not to mention highly detailed, we are still at a loss: we feel in the end that there are obstacles that prevent us from communicating, an awkwardness of accommodation that prevents us from gaining the essentials. ${ }^{26}$

Zheng Guanying expresses his feeling that, even if the Western languages themselves are simple, some essence in them lies just beyond translatability, without which the accumulation of discrete elements of knowledge is ultimately fruitless. It is hard not to see at work here the sort of totalistic thinking pointed out by such scholars as Lin Yu-sheng and Wang Hui and described in chapter 2.27 For all the accessibility with which the West seems to present itself, Zheng and others writing at the same time persist in feeling that something persistently blocks Chinese understand- 
ing of new ideas. Based on the belief that Western languages are fundamentally simple, however, they also hold out the hope that a key exists that will provide total and unmediated access to the secrets of Western wealth and power if only the right sort of effort is put forth. The problem is that no one can seem to find the key to the sort of effort that is required. For Yan Fu, this key seems to be science (kexue). As he wrote in 1902:

The reason Chinese politics becomes daily more deficient and shows itself as being incapable of surviving is that it does not base itself on science and thus diverges from universal principles and accepted practices. If one thus takes science as being identical with technology $(y i)$, then Western technology is in fact the root of Western politics. And even if one says that technology is not [in itself] science, then both politics and technology are derived from science, and they are like right and left hands. ${ }^{28}$

For Yan, then, science is the quintessence of the Western learning that must be adopted by China. In his assessment of how its transmission to China can be effected, Yan has much in common with Zheng. As the essay quoted above develops, Yan ends up putting even more stress on the general failure of piecemeal efforts to acquire Western knowledge. And despite his own significant efforts at translation, in this essay he stresses the need for people to master the original Western languages. Particularly germane to the purposes at hand, however, is the class inflection he puts on the ability to master his beloved science and the foreign languages and foreign ideas that underlie it:

There are those who wish to use Chinese to teach Western learning, with the idea that, even though the knowledge comes from the West, if we use our language to teach it, it will become our knowledge. This sounds excellent, but I am afraid that in light of present circumstances it is premature. In the trading cities on the coast, where missionary instruction has taken place, one meets constantly with those who can speak and write Western languages. ${ }^{29}$ But finding any capable of serving as science teachers is all but impossible - there are almost none. Those who wish to devote themselves to this learning (zhi qi ye) cannot translate without prior training, and even if they get hold of the books, those who would teach them cannot do so without first having a thorough understanding (xin tong). 30

Without disputing Yan's assertion of the shortage of qualified science teachers in China circa 1900, of interest here is his apparent dismissal of what was by then a reasonably extensive system of missionarysponsored education, which had long been devoting considerable effort to secular topics, particularly mathematics. ${ }^{31}$ Nor does he mention the 
extensive mathematics-based discourse on technological modernization that emanated from the Jiangnan Arsenal in the years after its founding in the $1860 \mathrm{~s}^{32}$ One gets the impression, if merely from the pedagogical lexicon he employs, that the only training in Western studies that Yan Fu would regard as really to the point would be that based on the sort of intense education/cultivation long associated with mastering the Confucian classics. Any more pragmatic, or experiential, absorption of Western language and culture would be disqualified from the lofty and absolutely essential task of penetrating to the definitive essence of Western learning, defined by him here as an all-embracing science.

One way to explain Yan's distinction between varieties of knowledge of the foreign would be simply to regard it as an attempt to preserve the monopoly on knowledge so long claimed by those with traditional educations. There can be no denying that this is at least partly true, but I think that more is at work here. By implicitly dividing up capacity in foreign language into two types - one a profound understanding conferred by first grasping the essence of Western learning, and the other a far more casual bricolage ${ }^{33}$ that lacks systematic application-Yan, like Zheng before him, creates under the rubric of science a special zone of rarefied knowledge of the foreign that will stand as a perpetual goad to the ordinary student who approaches the task of mastering foreign learning merely deductively. As part of the constant fear both men voice that too vulgar an approach will pollute any attempts to really master a highly arcane and all but unknowable West, the practical ability to naturalize Western knowledge regresses continually toward the horizon in formulations like these.

An episode that begins at the end of chapter 12 of Flower in a Sea captures with particular clarity some of the differences by which contrary modes of learning are articulated. As the new ambassador to Russiaamong other titles in his portfolio-Jin Wenqing naturally is greatly concerned about working out long-standing problems between Russia and China. The definition of the Sino-Russian border had been a prime object of contention between the two countries for some time, but the issue had became particularly acute in the nineteenth century. Jin thus takes exact delimitation of the border as a special concern. When the mysterious "M. Pierre" - who figured prominently in the novel in an earlier episode involving a swindle of Jin's money that I will discuss presently-shows up at the embassy in St. Petersburg with a decrepit map purporting to be a draft of the secret official version held in Russian government archives, Jin is anxious to acquire it. The price is one thousand gold pounds, but to Jin that exorbitant fee is simply an index to the map's true value. As Jin is in the process of asking for a reduction in price, Caiyun suddenly enters and says to herself: "Fine, he ["Pierre"] has been hiding this from 
me, and here he comes again to try to get hold of the old man's money! I won't let this one pass!" 34 She inquires as to what is happening, and when Jin tells her what the maps are, she blurts out at him: "Right you are! I was just about to ask you how much gold these old pieces of rotten paper are selling for. The drawing on them is fuzzy and not much to look at, so don't get taken." 35

At this point, Wenqing explains his motives in some detail, situating himself firmly in the Chinese academic context as he does so:

"Caiyun, smart as you are, this is something you do not understand. It was with great difficulty that I entreated this gentleman to secure this SinoRussian map. In the first place, I acquired this map to straighten out our country's borders such that foreigners will not be able to occupy so much as one inch of our territory, and also so as not to betray the trust the emperor placed in me when he sent me abroad. In the second place, it will provide reliable material for my Empirical Supplement to the Yuan History (Yuan shi buzheng) that I have poured ten years of my life into and still not published after all these years. So now when I return to Beijing, even the famous geographer of the northwest, Li Shinong, ${ }^{36}$ will have to admire my efforts. ..."37

Jin here announces himself to be the perfect scholar-official, for not only does he pursue the book in the national interest but he also has a profound academic agenda as well, and the book thus represents to him important cultural capital in the erudite world of metropolitan scholarship. He also announces himself to be completely within the ambit of traditional scholarly practice: everything about the method of learning he espouses here would have been recognized as valid throughout the entire late imperial period.

As her husband said, Caiyun does not understand any of this and proceeds to provide a sharply ironic commentary on Jin's sententious and self-regarding remarks:

"Don't be so proud of yourself. All day you carry around a couple of tattered old books, going around muttering to yourself, talking some kind of incomprehensible language: all this 'double-sound words, triplesound words, quadruple-sound words.' It's enough to fog up the mind and give me a headache. The one thing it does do is cause you to abandon your real work for three or four days at a time. All your talk about 'not so much as an inch of our territory!' If you ask me, even if somebody came and carried your own body away, you wouldn't pay any attention. I don't understand how, even if you get all the Yuan-dynasty names straight, you will assist the Qing in opening up the border and extending our land." 38 
In this, Caiyun proves to be prophetic, for the maps turn out to be forgeries that considerably understate China's actual historical landholdings in the border region (a scandal recounted later in the book, beginning in chapter 20). All Jin's years of study of Chinese geographical books are unable, in other words, to see through a foreign forgery that even the uneducated Caiyun instinctively suspected. What's more, Caiyun's pessimism extends to the notions of textuality that were so key to Chinese learning's vision of itself. Not only does she assume that the carefully prepared maps are so much wastepaper, but she also impugns the significance of Wenqing's years of attempting to wring meaning from old books, in effect anticipating some of the more radical pronouncements of the early May Fourth movement by some fifteen years. After all, there are not very many steps between Caiyun's cynical dismissal of Wenqing's belief that all solutions can be found in old texts and the radical iconoclasm of Lu Xun's "Madman's Diary" ("Kuangren riji”), in which yet another look at the classics reveals the shockingly negative reading embedded there: namely, that the key to Chinese culture is a positive injunction to engage in cannibalism. For all the horror of the madman's discovery, however, his insight is still based on a notion of textual authority that Caiyun almost completely discounts, revealing her, perhaps, as the more radical iconoclast of the two; there is no question whatsoever that she is the more vulgar and poorly educated.

The attention this exchange between Wenqing and Caiyun draws to the difference in their linguistic registers should also be noted. Whereas Wenqing throughout the novel speaks in a plain colloquial for ordinary conversational exchanges, Caiyun's utterances here are laced with a particular coarseness. A good example is the sequence that begins with "Don't be so proud of yourself. All day long you carry around a couple of tattered old books, going around muttering to yourself, talking some kind of incomprehensible language." The original Chinese is even clearer: "Laoye bie chuipang, ni yitian dao wan, baole jiben po shu, zuili jiligulu, shuoxie buzhong buwai de buzhi shemma hua ...." The words she uses to express her distance from the elaborate classical idiom of which Wenqing is master mark her as a thoroughly vernacular person and as being homologous to the linguistic simplicity that contemporary scholars regarded as the hallmark of the Western languages, at least as spoken in the treaty ports, and of the uneducated urban folk who were able to master them.

If Caiyun demonstrates a superiority in practical intelligence, however, the more we learn about her, the more her practical abilities become linked to a questionable moral status. As the episode continues after several narrative digressions back to China, we see Wenqing thinking that his acquisition of Pierre's map will ensure his mark as a great ambassador. His exclusive attention on his book soon is revealed as costing him 
more than simply attention to his ambassadorial duties. As the novel narrates the events of a typical day at the embassy, we suddenly learn how Caiyun spends the time when her husband is at work on his book: "Every day after Caiyun had completed her toilette, it was almost invariably just about time for lunch. She then went into the dining room and ate breakfast with Wenqing. When Wenqing went downstairs to his study to work on his Empirical Supplement to the Yuan History, he left Caiyun upstairs to exert herself strenuously at amorous pursuits, which he neither saw nor heard about." ${ }^{99}$ Although a prior chapter strongly hinted that Caiyun and $\mathrm{Ah} \mathrm{Fu}$, the youthful manservant assigned by Wenqing to attend upon her, have been engaging in illicit behavior, ${ }^{40}$ this is the first time it is made so explicit. And though Ah Fu may have been her first dalliance, he is by no means her last. What is of particular interest here, however, is the structural dichotomy between Wenqing's traditional scholarship and Caiyun's infidelity. To the extent that Wenqing devotes himself to his scholarship, Caiyun, in almost direct proportion, takes advantage of his inattention to her to carry on with other men. That his scholarship no longer has any practical application has already been alluded to and becomes even more evident as the novel draws on. But this portion of the episode also demonstrates that such scholarship no longer has any effective moral or personal function either. In fact, instead of illuminating the world, Wenqing's scholarly activity blinds him to its actual nature, thereby providing the most ironic commentary possible on traditional scholarship's diminished status in the new realm of things.

Caiyun's introduction to foreign languages had come earlier, on the boat taking her and Wenqing to Europe. The sum of the episodes on the boat introduced the notions so pointedly depicted in chapter 13 that traditional Chinese education was of less than no utility outside China, and it strongly hinted that the foreign brought along with it a loss of moral bearings. Before going into this, however, it would be worthwhile to sketch in the background to how a courtesan became an ambassador's wife in the first place. Wenqing had met the girl at an excursion of his friends on a pleasure boat where each of them was accompanied by a courtesan. Wenqing had been shown Caiyun and told that she was the "zhuangyuan" (optima) of courtesans; she was thus the perfect match for him. The two of them were smitten with one another immediately and shared a sense that they had somehow known one another in the past. ${ }^{41}$ Wenqing quickly took her as a concubine, even though he was still in mourning over the death of his mother. When he received his assignment to go to Europe, his principal wife, hearing that women in Europe were obliged to engage in numerous public functions, declined to go and suggested that Caiyun go in her stead, according her the privilege of wearing clothes appropriate only to the principal wife. 
Caiyun thus from the very beginning of her life with Wenqing transgresses the role that traditional practice would have assigned her, something quite serious in China. There sumptuary laws and other badges and insignia of rank fulfilled a crucial function of social differentiation in a country so large and diverse that more subtle signs of hierarchical status, such as accent or fashionable clothes, could not be counted upon to serve that function. As will be recalled from chapter 5, a similar transgression of dress code occurs in Wu Jianren's Strange Events, in which Gou Cai's concubine's usurpation of the clothes proper only for the principal wife marks the first signal of the disorder in the clownish Manchu's household. The only thing that renders Caiyun's transgression palatable is the demands of Western usage, in this case diplomatic etiquette. The transgression is perhaps best emblematized by the contrast between the significance accorded their respective titles of "zhuangyuan." The initial pairing of Wenqing and Caiyun had been based on their mutual "primacy" in their respective social realms: Wenqing in the world of indigenous scholarship, and Caiyun in the demimonde of prostitution. Given the social hierarchy out of which both designations arose, Caiyun's status as "optima" would originally have been an ironic back-formation on the dominant male pecking order. It is a sign of the disruption brought about by the coming of the West that Caiyun's ability to negotiate the new order grows exponentially as soon as the couple reach Europe. As her capacities develop, Caiyun's primacy loses its original ironic framing, with Wenqing and his formal title of "zhuangyuan" now becoming positioned as merely the residual ornaments of a passing regime. In the transit to the West, the irony attached to her title has gradually become transposed to his.

The switching places of the two characters is not immediately evident. During the first stages of the sea voyage to Europe aboard the German ship Saxon, Wenqing seems to be still in his element, enjoying himself aboard the ship and paying visits to locally eminent Chinese whenever they reach a new port. Caiyun, for her part, is seasick at first, although she recovers enough while in port to go ashore and enjoy seeing new things. Toward the end of the voyage, Wenqing encounters the Chinese-speaking "Pierre" ("Biyeshike"), described as a "famous Russian Ph.D.," in the act of hypnotizing three Chinese men. Wenqing is curious about the technique and asks Pierre to have one of the men reveal something about himself that he would not otherwise tell. Pierre objects to the impropriety involved in this but proceeds to ask the man anyway, and the latter promptly reveals sexual improprieties between himself and his employer's second wife that prove embarrassing to hear for all present, not to mention prophetic of Wenqing's cuckolding at the hands of $\mathrm{Ah} \mathrm{Fu}$, who coincidentally disappears while the story is being told. As all this is going on, however, Wenqing remains firmly in control and oblivious to any implications the 
story might have for his own future. Instead, he banters with a colleague about the significance of hypnotism. At this point, Wenqing suddenly sees a beautiful young foreign woman emerging from a passageway. Wenqing is fascinated by her and thinks it would be extremely interesting were she hypnotized. He does not dare ask Pierre directly to do this but devises a ruse to have him do it. Wenqing says that he thinks Pierre's hypnotizing of the first three men was prearranged, and to prove the true efficacy of hypnotism, Pierre would have to demonstrate his craft on someone at random, suggesting the young woman who has just come out on deck.

Pierre, having his veracity challenged in this way, agrees to hypnotize the woman before he even has a chance to get a good look at her. He duly puts her under his control and enjoins her to bring over a tray and set it on a small table in front of Wenqing, which she does in a manner that captivates the ambassador designate. Once Pierre sees who his subject actually is, however, he becomes extremely distraught and urges all the witnesses not to tell the young woman what has happened when she comes out of her trance. After she leaves, Wenqing asks Pierre the reason for his agitation and is told that the woman he had just put under is a famous Russian personage, known for her learning, capable of a large number of languages, and generally not someone to trifle with. Upon being told that her name is Sarah (Xiayali) ${ }^{42}$ and that her Chinese is excellent, Wenqing asks if Pierre might intercede by asking if Sarah would teach Caiyun a foreign language, something Pierre agrees to do after some persuasion. Wenqing learns the next morning that Sarah has, somewhat reluctantly, agreed to teach German to Caiyun, partly because they are all going to be in Germany for some time, so the lessons can continue. Sarah sets a wage of eighty marks a month. Caiyun is most enthusiastic and proceeds immediately to her first lesson. The text records Caiyun and Sarah as getting along very well and further remarks that "Caiyun was intelligent by nature, and within ten days could already communicate in the [new] language," an extraordinary feat by anyone's standard. ${ }^{43}$

The voyage and the events that take place on it mark the high point of Wenqing's powers of agency after leaving China. He seems at this point in the novel to be in control of the situations he encounters, and Caiyun plays only a small and rather passive role. The people who are later to cause him grief, notably the two women Caiyun and Sarah, are not threatening to him during all but the final stages of the journey. Neither is Ah $\mathrm{Fu}$, who remains definitely in a subsidiary position. The reader who has read the book more than once, however, can share the dramatic irony of the old man's confessions under hypnosis about his dalliance with his master's concubine that no one in the text (or no first reader) can know. The storm clouds are building around Wenqing, but there is no way for him to know what they ultimately portend, much as China's leaders in 
the nineteenth century could not apprehend what their ignorance of foreign codes of knowledge would augur for them and their country in the long run. Moreover, as it was for the more competent of late Qing officials, it is difficult to nominate any particular shortcoming or even series of misjudgments on Wenqing's part that can be seen as definitive signs of a change in his fortunes. He simply acts in ways that seem at the time to be essentially unexceptional and that only retrospectively turn out to be recognizable as errors. Even his subterfuge in persuading Pierre to hypnotize Sarah, although it arises out of improper, voyeuristic impulse, brings about consequences out of all proportion to the magnitude of the act itself. ${ }^{44}$ Significantly, the event that signals the end of Wenqing's fool's paradise comes just as the ship heaves in sight of Europe, in this case represented by the volcanoes of southern Italy.

What happens then is a shocking perturbation in the texture of the story as it has proceeded up to that point. In good storyteller style, at the end of chapter 9, just as Wenqing and Caiyun are getting out of their berths one morning, someone enters their cabin and demands in a cold voice that they answer a few questions, on pain of being shot. In turning the page to the next chapter, the reader discovers that the hand with the gun belongs to none other than Sarah, who has finally learned that she was hypnotized by Pierre and has now come to exact revenge on the ultimate agent of her humiliation. Speaking flawless Beijing Chinese, she generally insults the Chinese mandarinate ("Who would have thought that the more important a Chinese official was, the more inhuman he would be?" ${ }^{45}$ and compares her own strength and determination invidiously with what she calls the "good-for-nothing (worang) ways of your Chinese women." Even as she utters this, however, the actions of Wenqing and Caiyun contrast with one another in such a way as to render ironic at least her remarks about Chinese women, if not about the officials: "Hardpressed by [Sarah's] icy stare, Wenqing took several steps back and could say nothing at all. It was Caiyun who turned out to be the seasoned one; when she saw that things were not going well, she quickly stepped forward and grabbed Sarah by the shoulder." ${ }^{6}$ Then Caiyun tries to explain that the hypnosis had only been a random act, something that only Wenqing and the reader know is not quite the truth.

Just as Sarah is about to reply, the ship's German captain, Zhike, enters the cabin, and the contrast between Wenqing's and Caiyun's responses impresses itself upon the reader yet again: "As Sarah was about to open her mouth, the door of the cabin squeaked open and a short and powerful foreigner pushed his way in. Wenqing was again startled and thought to himself: 'It's all over. We can't even take care of one person and here comes another!' Caiyun took in everything in a moment and had instantly recognized the ship's captain, Zhike. She shouted out as 
quickly as she could: 'Mister Zhike, come in here and mediate for us!'” 47 Whereas Caiyun can instantly size up the situation as it develops and recognize which roles everyone should play, Wenqing is seized with panic and cannot even identify who the relevant players are. Zhike duly intercedes with Sarah, carrying on a long conversation with her in German and requesting that she not create an international incident by offending the Chinese ambassador to both of their countries, Germany and Russia. She relents but demands that there be some compensation for the insult. The captain had seen the badge of her political party, the name and nature of which are not revealed to the readers or to Wenqing and Caiyun. Captain Zhike suggests that she seek from the ambassador financial compensation for her suffering that she can turn over to the empty coffers of her party. Because the conversation is in German, Wenqing of course cannot understand a word of it, but Caiyun follows it completely, as her rapid mastering of German now begins to pay off for her.

Realizing the Wenqing will most likely accept any course of action that the captain suggests, Caiyun alertly takes advantage of her new bilingual status. When Sarah suggests, in German, that the "contribution" of Wenqing amount to ten thousand marks, Caiyun tells Wenqing the actual request was for fifteen thousand, thereby ensuring herself a sizable profit from her brief intercession in the affair. As the discussion in German takes place, Wenqing is again described as being completely at a loss: "For his part, Wenqing had long since collapsed in alarm, and he sat trembling on a couch. Since he did not understand German, when he saw them depart, he was both afraid for himself and dreading the outcome." When Caiyun imparts to him the amount of his "contribution," he is horrified by the size of the amount and asks Caiyun if she might go to the captain and ask him to lower the sum. Her reply is blunt and decisive:

"As for what just happened, if it had not been for me, you wouldn't even be alive by now. And now that you still have your life, you suddenly can't bear to part with your money! I advise you to save your energy. When somebody goes out on assignment, almost anybody can make eighty or a hundred thousand, so why are you getting so itchy about this little bit of money spent to save your life?"

Wenqing had nothing to say. 48

There has been an almost complete displacement here, with the initiative passing from Wenqing to Caiyun just as Europe comes within view. Caiyun's new capabilities would not be possible without her newly acquired German, but they certainly transcend the purely linguistic - she has been revealed as someone of great flexibility and intuition, who can adapt to new situations with ease. Her adaptability, in fact, seems to be in 
complementary distribution to Wenqing's helplessness in the face of the new and foreign. It is particularly noteworthy that although Caiyun's first instinct is to come to the defense of her new husband when he is placed in difficulty, she almost immediately figures out a way to turn her privileged situation to her own financial advantage, and at Wenqing's expense. Her almost instinctive selfishness cannot help but recall Yan Fu's and Liang Qichao's denunciations of the lack of a public spirit as a besetting flaw of the Chinese "national character." In other words, for all Caiyun's superficial ease at dealing with the foreign, Zeng Pu carefully represents her character in terms that progressive thinkers of the time were depicting as the fatal pollution resulting from unquestioned adherence to traditional behavior and its unexamined social debilities. ${ }^{49}$

The arrival at Europe also signals a transition in the narrative mode of the novel. Prior to chapter 10, although it was clear that Jin Wenqing was the narrative focalizer, the text was made up primarily of a diversity of stories and anecdotes about recognizable late Qing personalities. In this respect, it followed the form marked out by Wu Jingzi's classic eighteenth-century novel, Rulin waishi (The scholars), a form adhered to in broad outline by other late Qing works like Li Baojia's Wenming xiaoshi (Short history of civilization) and Wu Jianren's Strange Events. The emphasis in these early chapters of Flower in a Sea is on what we would now regard as gossip about famous people, particularly high officials, and it gives us penetrating sketches of the quirks of their personalities. Upon reaching Europe, however, even though the novel continues to provide interspersed anecdotes of goings-on in China, the story as a whole shifts to a concentrated focus upon Wenqing, Caiyun, and Sarah, with the plotlines concerning each of them carefully interwoven with one another. One is tempted to conclude here that even as the story resituates itself in Europe, the narrative mode effects the same type of transition as the story itself: it moves from the episodic linking together of anecdotes characteristic of the late Qing Rulin waishi tradition to the unity plot of high nineteenthcentury European fictional realism. This conclusion only gains credence from Zeng Pu's responses to criticism of the novel, in which he invokes his dedication to narrative craft. ${ }^{50}$

The revelation of Caiyun's shabby moral position emerges virtually simultaneously with her capacity to maneuver in the world, and the two aspects to her character are thereafter impossible to distinguish analytically. For a summary of Caiyun's character as she begins to perform as an independent agent, with a change of gender and substitution of "courtesan" for "merchant," her disposition as recounted in the novel accords remarkably well with Yen-p'ing Hao's description of the image of the nineteenth-century comprador, quoted in the notes to chapter 6: "Like any marginal man, he had his limitations. He was shrewd and talented but 
not always honest. Not an independent merchant per se from the beginning, he hung his hopes for success too closely on his connections with foreigners and thus on China's unstable foreign relations. He was still generally associated with the 'parasitic' merchant and was criticized for deviating from social norms." ${ }^{51}$ From this perspective Caiyun is just as far from escaping what the late Qing reformers perceived to be the flaws of traditional Chinese ways as is Jin Wenqing. Moreover, the utter incapacity for introspection or concern for values vouchsafed to her by her lack of Chinese education renders her particularly unlikely ever to move beyond her condition of moral depravity so as to achieve any sort of satisfactory intellectual synthesis.

For his part, Wenqing has the intricacies of Sarah's political persuasion explained to him directly after the incident is over. In demonstrating complete incomprehension of the Saint-Simonian socialist anarchism that she espouses, he reveals himself to be not just practically incompetent but also beyond the intellectual range of successful adaptation. In response to Wenqing's question as to what organization Sarah belongs, Pierre gives a detailed account in a utopian mode, including such visionary rhetoric as the following: "His [i.e., Saint-Simon's] point in establishing this organization was to transform false equality into real equalitywith no nationalist thought, no racialist thought, no familialism, and no religion. [He intended] to abolish money, to prohibit inheritance, to burst open all sorts of barriers, and to break out of all fetters. The emperor is the enemy, and the government is a bandit. If the country has important matters it must cope with, everyone in the country should discuss them and find ways to manage them." ${ }^{2}$ Wenqing's response and Pierre's reply to it throw further light on Wenqing's disposition and on the general situation in China:

When Wenqing heard this, he was so shocked that he blanched as he said: "If [what they believe] is as you say, then it is flat-out rebellion and sedition ( $d a$ ni budao) and they are an unlicensed party of insurrection. If these people lived in my country, they would long since have been subject to clear penalties. We simply would not have allowed them to pursue so boldly their damaging course of action!"

Pierre smiled as he said: "There is a principle at work here. Its not that I wish to insult your country, but in fact your people, when compared with other individuals, seem to be younger and more immature. Just at the time when they are groping their way along, they know only that they should be ruled by the emperor. Have they even heard of natural rights and the universal principle of equal rights? So it's easy to use force to coerce them. If you compare them with [the people of] my country [i.e., 
Russia], although the political systems are very similar, the people there have been enlightened, and they are not so easily fooled." 53

Because the time represented here is given as January 1888, much of the dramatic irony embedded in this exchange results from the narrative's having been produced some fifteen years later, when the views that Pierre describes and that Wenqing finds so horrifying had become commonplace among radical intellectuals. ${ }^{54}$ As early as 1895 even the by-then relatively cautious Yan Fu - cautious, at least, when compared with post1898 radicals like Zhang Binglin and Liu Shipei- hinted at views consonant with the Saint-Simonian anarchism to which Pierre gives voice. ${ }^{55}$ The clearly implicit social Darwinism with which Pierre compares the Chinese and Russian peoples is even more in accord with post-1895 intellectual fashion. Wenqing's shock at the novelty of these views, though certainly appropriate to an educated person in 1888 (particularly a high government official), thus seems naive and behind the times when gauged by the standards of readers in 1904 and after. The real point here, then, is again to show how ill-equipped those with a traditional education and the strict moral teaching imbricated within it are to deal with new ideas: just as he is unable to foresee what is in store for him as the Saxon approaches Europe, Wenqing seems unable even to begin to comprehend the broad range of Western learning, much less to recognize the extent of its implications for the new world that was just then coming into being within China.

Much of the commentary in English on Flower in a Sea focuses on how Caiyun's gender conditions how she treats others and how others treat her. Hu Ying, in particular, has dealt with the figuration of women, as emblems of the new and the uncertain. ${ }^{56}$ It must be stressed here, however, that the figuration of women in the novel, while dealing with the same issues, does not have a transparent relationship with whatever real struggles were going on at the time in China for female emancipation. As Partha Chatterjee says of this literary figuration: "The figure of woman often acts as a sign in discursive formations, standing for concepts or entities that have little to do with women in actuality." 57 The women in Flower in a Sea, and Caiyun more than any other, are deployed to represent certain choices available along the late Qing political spectrum. It would seem that the author manipulates female figures in this schematic way precisely because he regards them as eminently mutable and ultimately as lacking stable social natures. They thus constitute the emblem of difference for him and, as such, become the ideal vehicles for representing new and even dangerous versions of subjectivity. We might even see in Caiyun a replica of the figuration of the dangerous female whom Chatterjee describes in Ramakrisna's Kathāmrta: 
But in the particular context of the Kathämrta in relation to middle-class culture, the figure of woman-and-gold could acquire the status of much more specific sign: the sign of the economic and political subordination of the respectable male householder in colonial Calcutta. It connoted humiliation and fear, the constant troubles and anxieties of maintaining a life of respectability and dignity, the sense of intellectual confusion and spiritual crisis in which neither the traditional prescriptions of ritual practice nor the unconcretized principles of enlightened rationality could provide adequate guidance in regulating one's daily life in a situation that, after all, was unprecedented in "tradition." The sign, therefore, was loaded with negative meanings: greed, venality, deception, immorality, aggression, violence - the qualifications of success in the worlds both of commerce and of statecraft. 58

In keeping with this schematic view of the female, Wenqing's hopeless conservatism is represented by a basic incapacity to comprehend any of this female mutability, best embodied in the his final statement to Pierre, just before they part ways in a cloud of mutual suspicion: "Well, its one thing if men act this way, but how can women violate female propriety (bu jinshou guimen) by coming out and behaving in this reckless manner?" 59 Wenqing's notion of woman as someone who stays inside is thus tied to his inability to read the changes that are coming in China's direction. It is also a key indicator that the image of a new mobility for women has become a figure for the transformation of Chinese society itself. There is, however, a transparent irony here: Caiyun's act of assuming the clothes of the principal wife and appearing in public in Europe, depicted as one of the triumphs of Chinese diplomacy because of the enthusiastic reception accorded Caiyun, would have to be precisely the sort of "violation of female propriety" that Wenqing is addressing here. And even as he is about to fall victim to the very circumstances he protests here, he seems unable to link his instinctive response to Sarah's behavior to that of his own concubine. As I have tried to show, the rhetoric of the novel is notably ambiguous about Caiyun's transgressions of the traditional female role; they are at once seen as inevitable in her new circumstances and the cause of much anxiety. Jin's response thus falls at one end of this continuum of response to the new but is also portrayed as particularly blind to its own context. In other words, the discourse of modernity as it develops in this novel is distinctly ambivalent: the coming of the modern is seen as inescapable, but it brings with it a terrible amorality that gives no indication of any ready capacity for either rectification or rationalization.

In the scenes leading up to Jin Wenqing's horrible death, he both realizes the full extent of Caiyun's infidelity and attempts to pressure her into making some sort of declaration of regret for her disloyalty to him. 
Their failure to reach any sort of understanding in these final scenes is emblematic of a negative evaluation of the larger issue being figured throughout the novel: is there any way that the two kinds of knowledge represented by Wenqing and Caiyun can be brought onto the same horizon of understanding? Wenqing's full realization of Caiyun's perfidy is rendered all the more devastating by the public revelation of his error in accepting the validity of the erroneous maps he had sent back from St. Petersburg. When this comes to light, he is suddenly in deep trouble professionally, and when he learns the full extent of the trouble, he tries to take a brief rest, by himself and away from all the annoyances that surround him. While napping, he gets up in response to what he thinks is the noise of a mouse squeaking loudly, and when he goes out to chase it away, he suddenly faints and falls down. Caiyun is closest by and duly goes to attend him, only to be greeted by a cold, angry stare from a mute Wenqing when he reattains consciousness. When she reaches her hand into his bed to comfort him, he pushes it away angrily and blurts out: "Save your effort; now I recognize you for what you are!" And when she attempts to hand him a cup of tea, he slaps it away and spills it all over the bed. At this, she becomes angry in turn and throws the cup on the table with an angry snort.

This action angers Wenqing further, and he says to Caiyun: "How strange. You still have the nerve to sulk. All your defects are clear to me now, so just what kind of justification do you think you could possibly have?" ${ }^{60}$ Caiyun responds coolly, described by the narrator with cruel precision: "Who would have thought that Caiyun would show no fear but would merely concentrate on picking her teeth and looking straight up into the air? She smiled slightly as she said: 'I don't disagree; my flaws are all out in the open and there is nothing I can say about them. But I want to ask you one thing: Am I your proper wife or am I a concubine?'” This distinction is crucial for Caiyun. She says that if she were his proper wife, she would be loyal to the death and would deserve the worst sort of punishment for any transgression. Because she is only a concubine, however, she feels very different. She tells Wenqing:

You look at concubines simply as playthings. When we're getting along, you hug us and bounce us on your knee and call us all sorts of sweet names. But when things go bad, you chase us out or marry us off or even just give us to a friend. You might do anything. As for me, I have to say you've treated me pretty well, but you should have understood my basic nature, and you also should have understood where I came from. When you took me in, you never gave me any formal instruction in the moral regulations [proper to women] (san cong si de qi zhen jiu lie), 61 and so when I did a few things you didn't like, it shouldn't have come as such a sur- 
prise .... And now you want me to give up my immoral ways and go straight (gaixie guizheng). Ai ya! You can alter the course of rivers and move mountains, but it's hard to change someone's nature. I'm afraid you just don't have what it takes to make me serve you faithfully with everything I've got.62

This long expostulation transmits a shock of recognition to Wenqing: "each phrase was a knife, and each word drew blood." Caiyun's evocation of the class division between them strikes Wenqing particularly hard, evidently because he had given so little thought to it. Caiyun seems obsessed with it, however, at least insofar as it gives her license to behave in any way she pleases. A key part of her perception of this class difference is the lack of formal moral instruction given to someone of her station. She claims implicitly that these sorts of principles are only for those higher on the social scale than she. Later, after Wenqing has died and Caiyun has scandalized the Jin family with her failure to fulfill the proper role of widow by continuing to go out on the town, she begs to be released from her position in the household, explaining her own character in terms of extraordinary candor that are remarkably similar to, if less impassioned than, those she used to address Wenqing in the passage quoted above:

The master [i.e., Wenqing] always treated me with kindness. Since I am a person, how could I not be aware of this? So when he died and abandoned me midway through life, how could I not be sad when I thought of the feelings we had from almost a decade spent together? When the mistress [i.e., Wenqing's principal wife] said that I grieved properly during the mourning period [of forty-nine days] and intended to observe [the proprieties of widowhood], it's true, and it also expressed my true feelings. At the time, I wanted to strive to do something for him and to win him a good name. But I was given this evil temperament that needed to be busy all the time and craved pleasure, and when opportunities offer themselves, I just can't control myself. If you insist on keeping me here at home, I can't guarantee that some sort of ugliness won't happen, and once it reaches that point, it will be even worse for the master's memory. What's more, I spend freely, and because I never learned any of the principles of how to be frugal and because of my basic nature, once I arrived here, I got used to spending money lavishly. 63

Caiyun's self-analysis, when contrasted with the well-bred environment in which she had been placed, raises a complex of issues. The first centers on the educability of that indeterminately large group of people below the Confucian-educated elite, which was, as we saw in chapter 4 , cited as the one of the justifications for the attention to the novel in the 
late Qing intellectual world. As was clear from the moment Caiyun and Wenqing came within sight of Europe, to the extent that Caiyun represents this less educated group, that group was perceived within the rhetorical position of the novel to be much better able to handle the purely technical demands of the new world than the Confucian elite. The quintessential moral standing that had always been the central tenet of the Confucian teaching, however, is painfully absent in Caiyun's character once she is exposed to different opportunities. That Caiyun has lived in a proper household for such a long time and still seems not to have absorbed any of the deep moral tradition that such families took so much pride in sounds a profoundly pessimistic note as to the possibility for this morality to be inculcated in society as a whole. ${ }^{64}$ The gap between $d a o$ and qi (implementation) that Chen Chi and many others had been so concerned with in the years before 1900, which was discussed in chapter 1 , seems to have grown even more since the imperfectly or inadequately educated population has become involved.

It is important to note, however, that class difference is not the only thing invoked here, for early in the novel a concubine is introduced who is the model of widowly propriety. In chapter 3, as part of Jin Wenqing's triumphant homecoming after winning his degree, he and his friends visit the home of Chu Ailin, a courtesan and former mistress of the late Gong Xiaoqi, a character modeled after Gong Cheng (b. 1817), son of the famous iconoclastic scholar Gong Zizhen (1792-1841). When his friend Lu Renxiang (Bengru), also a zhuangyuan (based on the historical figure Lu Runxiang [1841-1915], optimus of 1874), first informs him that their group of friends is going to visit a courtesan, Jin is surprised, thinking that they should be above such vulgar pursuits. Another of the men in the circle explains: "I used to think this way myself, but later I learned that this Chu Ailin is not just a common whore who can be called out by anybody. Not only can she sing song sets (daqu) and short lyrics (xiaoling), but she is also mentioned in the Banqiao zaji. ${ }^{65}$ Moreover, her residence is filled with antiques, old paintings, and heirloom inkstones. She is a veritable female connoisseur!" 66 The contrast between Chu Ailin and Fu Caiyun could not be clearer here: whereas Chu is steeped in the cultural trappings of the Chinese tradition, there is almost no mention of such attainments in connection with Caiyun. In fact, the one place in the novel where Caiyun does demonstrate that she can sing is on the terrace of the Chinese embassy at St. Petersburg, accompanied by Ah Fu on the organ, ${ }^{67}$ creating a spectacle portrayed as being as gross and déclassé as the character of Chu Ailin is refined.

These differences in cultural attainment between the two women serve as indices of more profound contrasts below the surface. Whereas Caiyun never fails to place her own interests ahead of everyone else's, 
most notably those of Jin Wenqing and his family, Chu Ailin goes to great lengths to defend the memory of her late consort. When Wenqing and Ailin meet, she realizes that she has met him before and asks him about a prior concubine he had had in Yantai before he passed the metropolitan examinations. Because Jin had callously discarded her, he does not wish to be reminded of the connection. He becomes irked and proceeds to ask Ailin a series of hostile questions. Instead of unmasking any hidden flaws, however, her coolness in response to Wenqing's truculence only demonstrates the true dignity of her character. He first asks her if she has not simply run out on Gong Xiaoqi, taking with her all the cultural artifacts that now surround her in her lodgings. She replies that he had sent her away to make her own living, because through his spendthrift ways he had been reduced to desperate poverty and could no longer support her. He gave her all the valuable things she has as souvenirs of his enduring affection. Wenqing goes on to press her on Xiaoqi's perfidy in accompanying the British to the Summer Palace in 1860 and advocating that the British burn it down. Wenqing assumes that Xiaoqi turned traitor strictly as a way of getting his hands on more money, a conclusion that Ailin immediately takes pains to dispel. She tells a long and lurid story of how Xiaoqi's father (clearly Gong Zizhen, although never explicitly named) had been seduced by a princess of a Mongolian Banner and had been poisoned for revenge by her family once they found out about it. Xiaoqi's actions in participating in the burning of the Summer Palace were thus to avenge the death of his father, even though father and son never got along very well. Chu Ailin thus seeks to promote Xiaoqi's legacy as a man of surpassing filiality, the cardinal Confucian virtue.

In Chu Ailin and Fu Caiyun we thus see two very different women, whose figuration runs in diametrically opposed directions. The novel seems to indicate that Ailin's moral strengths are as homologous with her cultural attributes as Caiyun's amorality is with her lack of refinement. Furthermore, the intense "Chinese-ness" of Ailin's public personalitynotably her profound cultural attainment - is as marked as Caiyun's ease of connecting with, and ability to manipulate, the foreign. In analyzing the novel as a whole, then, this is yet another demonstration that the figuration of the female in late Qing fiction is never simple. As in Wu Jianren's Strange Events, the traditional female in Flower in a Sea embodies the best of the traditional virtues, more so than the men surrounding her, who are portrayed as distinctly problematic-Xiaoqi is a spendthrift who sold out his country for the sake of filial obligation and Wenqing is a faithless lover. Once the female is separated from familiar cultural practices, however, she suddenly becomes dangerous. Without the paraphernalia of traditional ways to hem her in, Caiyun becomes promiscuous both culturally and sexually. While she seems to represent the coming of the new 
order, her peculiar coldness to customary notions of reciprocity renders her a highly ominous model for the new, foreign-oriented age to come.

It is equally important to note that Caiyun does not simply represent the foreign per se. The Russian revolutionary Sarah, another woman who figures prominently in the text, stands in as someone who seems in most ways to be the emblem of the modern Western woman. As we saw when she threatened Wenqing and Caiyun over the hypnosis incident, she is portrayed as someone with a strong sense of herself and perhaps even a salutary model for Caiyun, who spends considerable time with her studying German as the Saxon approaches Europe. It is, for instance, noteworthy that Sarah tells Caiyun during the course of her dispute with Wenqing that she will continue to give German classes as before - the Russian woman is steadfast in holding that her dispute with Wenqing has nothing to do with the relationship between the two women. ${ }^{68}$ Sarah, however, also figures as a person willing to subordinate any personal loyalties to the political program of the anarchist party, demonstrating the most steadfast loyalty to its goals, even to the point of attempting to assassinate the czar.

Sarah would thus seem to represent one end of the continuum of possible human conduct, in this case the commitment to the commonweal that Yan Fu and Liang Qichao had established as such a defining characteristic of Western social and political behavior. In analyzing Sarah, however, one must keep in mind Pierre's remarks to Jin Wenqing about the relationship between China and Russia. In saying that their political systems resemble one another, but that the Russian people had already "been enlightened" and "are not so easily fooled," ${ }^{69}$ Pierre is, in effect, putting China and Russia on an evolutionary continuum. If Germany and England are envisioned as being part of an incomparably different and more advanced world, then Russia is halfway between, with a political system similar to that of China but with a people that has already begun to wake up. Sarah can thus serve as a model of personal progress, and her ability to converse readily in both Chinese and European languages demonstrates her to be in many ways the mirror image of the flexible Caiyun. The clear difference in fundamental character between them, however, points to the vast differences in political awareness between the peoples of the two countries. ${ }^{70}$

As it is retrospectively introduced to the reader, Sarah's political behavior does have problematic implications for the more personal side of her life. Only after the events leading to her arrest does the narrator recount her personal history, in an extended sequence more characteristic of an adventure novel than of the rest of Flower in a Sea. To render a long and complicated story briefly and simply, Sarah, after initially being portrayed as a heartless opportunist, turns out to be both politically brave and personally loyal, demonstrating her profound affection 
for her lover before she is executed for her attempt on the czar's life. To make the contrast between Sarah and Caiyun as acute as possible, as soon as this long sequence relating Sarah's heroism is wrapped up, the narration switches back to an account of another of Caiyun's illicit affairs, this time with a dashing young German officer, Count Waldersee. The juxtaposition of episodes here only emphasizes the contrast between Sarah's selflessness and Caiyun's self-indulgent hedonism. The much-remarkedupon fact that Zeng $\mathrm{Pu}$ did not extend his narrative to the aftermath of the Boxer Rebellion in Beijing - where Sai Jinhua, the model of Caiyun, was rumored to have performed notable acts of public service-stands as another example of the author's determination to portray Caiyun in as selfish a light as possible. ${ }^{71}$

When juxtaposed with one another, the different developmental trajectories among these three female characters suggest three possibilities for behavior in the environment China found itself in at the end of the nineteenth century. Together they represent the polysemy of the figuration of the female: there exists a large range of possibilities, both good and bad. Chu Ailin represents a highly traditional image of the Chinese woman: she dedicates herself to personal loyalty, thereby exhibiting the best side of the private virtues set out by contemporary thinkers as emblematic of the Chinese character. Sarah, for all that she is obliged to betray her personal loyalty to her lover Kelansi, turns out to have done it all for a noble cause, for which she most admirably martyrs herself. In the end, her selfless dedication to the cause justifies any of the apparent harshness of her personal behavior. At any rate, the scene where Kelansi observes her crying over his photograph demonstrates that personal loyalty had always been a core element of her character. Caiyun, however, in her relentless pursuit of personal advantage, combines the worst of both the other worlds: she manifests a profound instinct for her individual interest, but without any of the personal loyalties that would give it the sort of social meaning that Chu Ailin so richly embodies. And in contrast to the imposing Sarah, the only principle Caiyun seems to stand for is advantage to her own self. For all the technical education (i.e., the instruction in German) she receives from Sarah, Caiyun in the end is as completely impervious to the grander, selfless side of Sarah's Westernized character as she was to the moral influences of the Jin household and its strict notions of Confucian propriety. Above all, Caiyun seems to figure the impossibility of the realization of the utopian potentials represented in the other two women. She is thus very much the embodiment of a characteristic late Qing frustration: a most vivid representation of the inability to bring about any local application of the virtues that have been discovered in a newly widened world. 